\title{
Relationship between disaster knowledge and environmental culture with disaster preparedness behaviour
}

\author{
Rosadi $^{1,2}$, Isman Kadar ${ }^{2}$ and Yossa Istiadi ${ }^{2}$ \\ ${ }^{1}$ Yayasan Pendidikan Mentari Ilmu, Jl. Soka No. 25, Guro, Karawang 41314, West Java, Indonesia \\ ${ }^{2}$ Magister Programme of Environmental Management, Graduate School of Pakuan University, Jl. Pakuan Kotak Pos 452, Bogor \\ 16129, Indonesia
}

Corresponding author: Rosadi, E-mail: rosadi_18@yahoo.com

\begin{abstract}
This research consists of two independent variables, the disaster knowledge and environmental culture, and a dependent variable of disaster preparedness behaviour. The objective is to determine the relationship between disaster knowledge and environmental culture with disaster preparedness behaviour, as well as the relationship between both of the together with disaster preparedness behaviour. The study was conducted through 166 students of three senior high schools in the District of West Karawang, West Java, which taken by proportional random sampling. The method of survey was employed in this study and the data analyzed by statistical test of correlation and simple linier regression as well as multiple linear correlation and regression, which was conducted at significance level of $a=0.01$ and $\alpha=0.05$. Based on the results, it was found that there was a positive and significant relationship between disaster knowledge and disaster preparedness behaviour with a correlation coefficient value of $\mathrm{ry}_{1}=0.22$ and a coefficient of determination value of $\left(\mathrm{r}^{2}\right)=$ 0.049. There is a positive and significant relationship between environmental culture and disaster preparedness behaviour with a correlation coefficient value of $r \mathrm{y}^{2}=0.25$ and a coefficient of determination value of $\left(\mathrm{r}^{2}\right)=0.064$. There is a positive and significant relationship between disaster knowledge and environmental culture together with disaster preparedness behaviour with a correlation coefficient value of $\mathrm{ry}_{12}=0.32$ and a coefficient of determination value of $\left(\mathrm{r}^{2}\right)=0.097$. Thus, it can be concluded that student's disaster preparedness behaviour can be improved through either disaster knowledge and environmental culture.
\end{abstract}

\begin{abstract}
ABSTRAK
Penelitian ini terdiri atas dua variabel bebas, pengetahuan kebencanaan dan budaya lingkungan, serta satu variabel terikat yaitu perilaku siaga bencana. Tujuannya untuk mengetahui hubungan antara pengetahuan kebencanaan, budaya lingkungan dengan perilaku siaga bencana, serta hubungan keduanya secara bersama-sama dengan perilaku siaga bencana. Penelitian dilaksanakan melalui 166 siswa di tiga sekolah menengah atas, Kecamatan Karawang Barat, yang diambil secara proporsional random sampling. Metode survey digunakan dan data dianalisis dengan uji statistik korelasi dan regresi sederhana serta korelasi dan regresi linear ganda, dilakukan pada taraf signifikansi $\alpha=0,01$ dan $\alpha=0,05$. Hasil menunjukkan bahwa terdapat hubungan positif dan signifikan antara pengetahuan kebencanaan dengan perilaku siaga bencana dengan nilai koefisien korelasi $\mathrm{ry}_{1}=0,22$ dan koefisien determinasi $\left(\mathrm{r}^{2}\right)=$ 0,049. Terdapat hubungan positif dan signifikan antara budaya lingkungan dengan perilaku siaga bencana dengan nilai koefisien korelasi $\mathrm{ry}_{2}=0,25$ dan koefisien determinasi $\left(\mathrm{r}^{2}\right)=0,064$. Terdapat hubungan positif dan signifikan antara pengetahuan kebencanaan dan budaya lingkungan secara bersama-sama dengan perilaku siaga bencana, dengan nilai koefisien korelasi ry ${ }_{12}=0,32$ dan koefisien determinasi $\left(\mathrm{r}^{2}\right)=0,097$. Jadi, dapat disimpulkan bahwa perilaku siaga bencana siswa dapat ditingkatkan melalui pengetahuan kebencanaan dan budaya lingkungan.
\end{abstract}

Keywords: Direct seeding, seed briquette, Gmelia

\section{INTRODUGTION}

Indonesia is a country that is in the path of the most active earthquake in the world because it is surrounded by the Pacific Ring of Fire and are on top of three continental plates colliding, namely, Indo-Australia from the south, Eurasia from the

Submitted 01 November 2019; Accepted 16 March 2020 north, and the Pacific from the east. $\mathrm{T}$ his geographical condition on the one hand makes Indonesia an area prone to volcanic eruptions, earthquakes and tsunamis.

Based on data on Indonesian disaster information released by the National Disaster Management Agency (BNPB) during the past five 
years, disaster events have increased in 2017 recorded 2,853 events and those that experienced the greatest impact occurred in 2018 with the number of people affected by disasters by 10,333 . 309, as many as 4,814 people were killed and 1,736 units of school facilities damaged.

Karawang Regency, West Java, Indonesia, is located at thecoordinates between $107^{\circ} 02^{\prime}-107040^{\prime}$ East and $5^{0} 56^{\prime}-6^{0} 34^{\prime}$ 'South, bordering Bekasi and Bogor Regencies in the west side, Java Sea in the northern side, Subang Regency in the east, Purwakarta Regency in southeast, and Cianjur Regency in the southern side. The size of the area of Karawang Regency is $1,737.53 \mathrm{~km}^{2}$ with a population of 2,125,234 people. Most of the Karawang regency area is in the lowland, and only a small part is plateau in the southern region.

Based on Indonesian disaster information data that was released by BNPB during the past ten years, the type of disaster that occurred in Karawang Regency i.e. 42 events of flooding that affected 752,333 people, then the putting beliung tornado disaster 23 events which affected 657 people, then landslides 3 events that affected 73 people, while last one was drought.

Therefore, seeing the data presented above shows that our country is susceptible to disasters. In general, the level of preparedness of the community and regional government in dealing with major disasters is not yet ready. Disaster mitigation, disaster preparedness and disaster risk reduction still need to be improved. Disaster risk reduction must be interpreted as an investment in national development. Without the preparedness, the impact of disasters will always cause heavy casualties and huge economic losses.

Chang-Richards et al. (2017) suggested that disaster preparedness is often referred to as action taken before an event that reduces or can help reduce and eliminate the severity of natural disasters by preparing communities or people through developing contingency plans for response and recovery, quick plans and effective, and ongoing public awareness about hazards and risks.

Community preparedness tends to be ignored by the government who will make decisions (Dodon, 2013). So far, there are still many people who depend on preparedness and mitigation to the government by ignoring their personal preparedness.
Pebriati and Erly (2013) argued that disaster knowledge is the ability to remember events or series of events that threaten and disrupt people's lives and livelihoods caused, both by natural and / or non-natural factors as well as human factors that can result in human casualties, environmental damage, property loss, and psychological impacts.

Duval and Bovalino (2000) suggested that to reduce the risk of disaster, its highly important to increase the understanding it through the knowledge. One way to increase awareness is to improve someone's knowledge of something. For example, when children's knowledge of disasters is good, it can create a generation that is resilient to disasters and has good preparedness for disasters.

Rivai and Mulyadi (2010) suggested that environmental culture as a philosophy that discusses human responsibilities and obligations. Elena (2015) suggested that environmental culture is an integral category that includes many components, among which the most frequently mentioned are cognitive, emotional aesthetic, semantic and active values.

Disasters are events that are caused by natural factors and non-natural factors are also caused by human factors themselves so that disaster preparedness behaviour is very important in anticipating the threat of danger and appropriate action when a disaster occurs in order to minimize the incidence of fatalities, environmental damage, property losses and psychological impacts. Disaster preparedness behaviour is not only needed for people in disaster-prone areas, but it is also needed for everyone, this is because disaster events cannot be predicted when and where they will occur, with the provision of disaster preparedness behaviour owned, someone will be prepared in facing disasters. anytime and anywhere.

Based on previous research, disaster knowledge and environmental culture influence disaster preparedness behaviour. Someone who has the knowledge of disaster and environmental culture attitudes in their daily lives will influence someone's behaviour to be prepared in anticipating disasters and carry out protection activities or preparedness efforts. Therefore, the better of the knowledge of disaster and the environment culture of someone, then the disaster preparedness behaviour will also be good.

The availability of special subjects on disaster-based environmental education does not yet exist in formal education, so there is insufficient 
awareness of the younger generation to care for the preservation of their surrounding environment. When the maintenance and preservation of the environment has become their culture, then over time the disaster preparedness behaviour will also be good. Thus, disaster-based environmental education to reduce disaster risk is very important.

Based on the description above, it is deemed necessary to conduct further research related to disaster preparedness behaviour in the education sector. So far, studies related to disaster preparedness behaviour are still very little, particularly in-depth study related to disaster knowledge and environmental culture of students' disaster preparedness behaviour.

Based on this background, this paper raises the study of disaster preparedness behaviour in relation to disaster knowledge and environmental culture within high school students in the District of Karawang Barat, Karawang, West Java. Objectives of this study is first, to seek the relationship between disaster knowledge and disaster preparedness behaviour. Second, to understand the relationship between environmental culture and disaster preparedness behaviour Third, to find out the relationship between disaster knowledge and environmental culture both together with disaster preparedness behaviour.

\section{METHODS}

This research was conducted within three state senior high schools in West Karawang District, Karawang Regency, West Java. This study employed a survey method with a correlational approach. The research variables consisted of two independent variables namely disaster knowledge $\left(\mathrm{X}_{1}\right)$ and environmental culture $\left(\mathrm{X}_{2}\right)$ and a dependent variable namely disaster alert behaviour $(\mathrm{Y})$.

The population of this study was 258 students of class XII IPS that scattered in West Karawang District, Karawang Regency. The sample in this study was taken using the proportional random sampling, which is a technique for proportional populations.

Field data collection was carried out with a questionnaire to obtain data about disaster preparedness behaviour, disaster knowledge, and environmental culture. Data analysis was conducted using descriptive statistical analysis techniques, analysis prerequisite tests which include normality tests and homogeneity tests. Simple correlation test of analysis techniques and multiple correlation tests as well as the analysis of the coefficient of determination were employed to test the research hypothesis.

\section{RESULTS}

Based on the results of hypothesis testing, there is an evidence that the three hypotheses proposed can be significantly accepted. Overall this study shows there is a positive relationship between, 1) the relationship between disaster knowledge and disaster preparedness behaviour, 2) the relationship between environmental culture and disaster preparedness behaviour, 3) the relationship between disaster knowledge and environmental culture both together with disaster preparedness behaviour.

\section{Relationship between disaster knowledge and disaster preparedness behaviour}

The result shows that there was a positive and significant relationship between disaster knowledge $\left(\mathrm{X}_{1}\right)$ and disaster preparedness behaviour (Y) as indicated by the correlation coefficient value $\mathrm{r}_{\mathrm{y} 1}=$ 0.22. The coefficient of determination $\mathrm{r}^{2}=0.049$ and the simple linear regression equation $\hat{\mathrm{Y}}^{\mathrm{y}}=51.45+$ $0.94 \mathrm{X}_{1}$ means that disaster knowledge $\left(\mathrm{X}_{1}\right)$ contributes to disaster preparedness behaviour of $4.9 \%$.

\section{Relationship between environmental culture and disaster preparedness behaviour}

The result shows that there was a positive and significant relationship between environmental culture variables $\left(\mathrm{X}_{2}\right)$ with disaster alert behaviour variable $(\mathrm{Y})$. This is indicated by the correlation coefficient $\mathrm{r}_{\mathrm{y} 2}=0.25$, and the coefficient of determination $r^{2}=0.064$ on simple linear regression equation $y=11.98+0,50 \mathrm{X}_{2}$ which means that the contribution of environmental culture $\left(\mathrm{X}_{2}\right)$ to disaster alert behaviour of $6.4 \%$.

\section{Relationship between disaster knowledge and environmental culture both together with disaster preparedness behaviour}

The result of the study shows that there is a positive and significant relationship between disaster knowledge $\left(\mathrm{X}_{1}\right)$ and environmental culture $\left(\mathrm{X}_{2}\right)$ variables both together with the disaster preparedness behaviour variable $(Y)$, which is indicated by the value the correlation coefficient $r_{\mathrm{y} 12}=0.31$. The coefficient of determination $\mathrm{r}_{\mathrm{y} 12}^{2}=0.097$ indicates that disaster knowledge $\left(\mathrm{X}_{1}\right)$ and environmental culture $\left(\mathrm{X}_{2}\right)$ both 
together contribute to disaster preparedness behaviour $(\mathrm{Y})$ of $9.7 \%$.

\section{DISSGUSION}

\section{Relationship between disaster knowledge and disaster preparedness behaviour}

Based on simple linear regression equation $\mathrm{y}=$ $51.45+0,94 \mathrm{X}_{1}$ predicted that every increase in one score of disaster knowledge will cause an increase of 0.94 score on disaster alert behaviour at a constant of 51.45. The result of this study concluded that the disaster knowledge possessed made a positive contribution that significantly affected the disaster preparedness behaviour (Bhosale, 2015).

Based on the fact and data findings in the analysis of this study, the strength of the relationship between disaster knowledge and disaster preparedness is weak. Based on data descriptions the average score of students' disaster knowledge is 25 and the average score of students' disaster preparedness behaviour is 75, this shows that students' knowledge of disaster preparedness and behaviour is still low. Based on the observation, it was found out that students got disaster knowledge when they learned in class precisely on the subject of Geography and the material is only one chapter and that knowledge has not been fully applied in daily life due to lack of training or simulations in practicing disaster preparedness behaviour both in the school environment, their residence or in the community.

Based on the results of research and discussion above, it can be indicated that one of effort to improve disaster preparedness behaviour is to increase or develop disaster knowledge and conduct simulations or exercises regularly (Alonso et al., 2017).

\section{Relationship between environmental culture and disaster preparedness behaviour}

The pattern of relationships between environmental cultural variables with behavioural variables declared that the disaster preparedness with equation simple linear regression is $11.98+0,50 \mathrm{X}_{2}$. It is predicted that each increase in one score environmental culture will cause an increase of 0.50 score disaster preparedness behaviour at constant of 11.98. The existence of a positive relationship between environmental culture and disaster preparedness behaviour shows that the role of environmental culture will help achieve disaster preparedness behaviour.
The fact and data findings in the analysis of this study, the strength of the relationship between environmental culture and disaster preparedness is weak. Based on the data description the average score of students' disaster preparedness behaviour is 75, this shows that the students' disaster alert behaviour is still low (Carter, 2008). Based on the search that the environmental culture that students do in the form of attitude towards environmental conditions and not fully the attitude is followed up or applied in daily life in relation to disaster preparedness behaviour both in schools and residences, as well as in the community.

\section{Relationship between disaster knowledge and environmental culture both together with disaster preparedness behaviour}

The findings of this study indicate that disaster knowledge and environmental culture both together are mutually supporting factors to achieve maximum disaster preparedness behaviour. With good disaster knowledge and with the support of a good environmental culture, a student will increase his disaster preparedness behaviour (Hunt, 2006; Issa et al., 2017).

\section{DISSCUSION}

There is a very significantly positive relationship between disaster knowledge and disaster preparedness behaviour. The level of the relationship is indicated by the correlation coefficient of 0.22 while the coefficient of determination of 0.049 . This means that the contribution of disaster knowledge to the variable of disaster preparedness is $4.9 \%$. The functional relationship between disaster knowledge and disaster preparedness behaviour meets the regression equation $\mathrm{Y}=51.446+0,9406 \mathrm{X}_{1}$ and the association is significant. Second, there is a very significantly positive relationship between environmental culture and disaster preparedness behaviour. The level of the relationship is indicated by the correlation coefficient of 0.25 while the coefficient of determination of 0.064 . This means that the level of the contribution of environmental culture variables to the variable of disaster preparedness behaviour is $6.4 \%$. The functional relationship between the environmental culture and disaster preparedness behaviour meets the regression equation $\mathrm{Y}=11.976+0,5047 \mathrm{X}_{2}$ and the association is significant. Third, there is a very significantly positive relationship between disaster knowledge and 
environmental culture both together with the disaster preparedness behaviour. The level of the relationship is indicated by the correlation coefficient of 0.32 while the coefficient of determination of 0.097. This means that the level of the contribution of disaster knowledge and environmental culture variables both together to the variable of disaster preparedness behaviour is $9.7 \%$.

\section{AGKNOWLEDGMENTS}

The first author would like to express his thank to Mr. Saepul Muhtadin and Dwito Laksono (Boards of Yayasan Pendidikan Mentari Ilmu, Karawang), as well as the foundation chair, Mrs. Eka D. Nuraeni, who has given her fully support to this study. A highly appreciation given to all colleagues and teachers at the foundation.

\section{REFERENCES}

Alonso, E.B, Cockx, L., and J. Swinnen (2017). Culture and food security. LICOS Discussion Paper Series No. 398. LICOS Center for Institutions and Economic, Leuven, Belgium.

Bhosale, S.K. (2015). The Concept of ecology and environment. Foundation Course Semester 2, VPM's B.N. Bandodkar College of Science, Thane. http://dspace.vmthane.org [accessed 24 January 2019].

Carter, W.N. (2008). Disaster Management: A Disaster Manager's Handbook. Asian Development Bank, Mandaluyong City, Philippines.

Chang-richards, A., Richards, J., Bubb, J. and M.K. Rañeses (2017). Measuring the level of disaster preparedness in Auckland. Procedia Engineering 212:419-426.

Dodon. (2013). Indikator dan perilaku kesiapsiagaan masyarakat di permukiman padat penduduk dalam antisipasi berbagai fase bencana banjir. Jurnal Perencanaan Wilayah dan Kota 24(2):125-140.

Duval, T.S., and K. Bovalino (2000). Tornado preparedness of students, nonstudents, renters, and nonstudent owners: issue of pre-theory. Fournal of Applied Social Psychology 30(6):1310-1329.
Elena, V. (2015). The development of ecological culture of students in the design and creative activity. Procedia-Social and Behavioral Sciences 191:2329-2333.

Hunt, D.P. (2006). The concept of knowledge and how to measure it. Fournal of Intellectual Capital 4(1):100-113.

Issa, A.H., Wahab, H.A. and N.A. Abdullah (2017). Depleted uranium violates human right in the environment. International fournal in Management and Social Science 5(3):321-333.

Pebriati and Z. Erly (2013). Pengaruh model pembelajaran terpadu pada pengintegrasian materi pengurangan resiko bencana dalam mata pelajaran IPS SMP terhadap pengetahuan dan kesiapsiagaan bencana. Jurnal Bumi Lestari $\mathbf{1}(\mathbf{1}): 11-20$.

Rivai, V. and D. Mulyadi (2010). Kepemimpinan dan Perilaku Organisasi. Raja Gafindo Persada, Jakarta, Indonesia. 